\title{
EVALUASI KARAKTERISTIK PETERNAK TERHADAP PRODUKSI SAPI BALI DI KABUPATEN BELU, NUSA TENGGARA TIMUR
}

\author{
Edelnia Kristina Bere ${ }^{1}$, Rifa' ${ }^{2}$ \\ ${ }^{1}$ Program Studi Peternakan, Sekolah Tinggi Pertanian Flores Bajawa \\ Jl. Pierre Tandean, Tanalodu, Bajawa, Ngada, Nusa Tenggara Timur \\ 86413 \\ ${ }^{2}$ Program Studi Peternakan, Fakultas Peternakan, Universitas \\ Kahuripan Kediri \\ Jl. Soekarno Hatta, Pallem, Kec. Pare, Kediri, Jawa Timur 64213 \\ Email: niabere4@gmail.com
}

\begin{abstract}
Abstrak
Tujuan dari penelitian ini adalah untuk mengetahui pengetahuan masyarakat tentang manajemen pemeliharaan sapi Bali. Penelitian ini dilaksanakan di kecamatan Tasifeto Timur dan Tasifeto Barat di Kabupaten Belu, Nusa Tenggara Timur pada bulan Oktober-Desember 2018. Permasalahan yang ingin diketahui adalah bagaimana karakteristik peternak terhadap produksi sapi Bali. Metode penelitian dengan melakukan wawancara kepada 50 orang responden peternak. Teknik purposive sampling digunakan dalam penelitian ini dan variabel yang diamati antara lain: tingkat pendidikan, umur beternak dan lama beternak terhadap produksi sapi Bali. Analisis statistik deskriptif digunakan untuk menggambarkan karakteristik peternak. Hasil dari penelitian adalah karakteristik peternak sapi Bali di kecamatan Tasifeto Timur dan Tasifeto Barat Kabupaten Belu berdasarkan tingkat pendidikan sebagian besar hanya mengayomi pendidikan Sekolah Dasar sebanyak 27 orang atau 54\%, umur beternak rata-rata 25-54 tahun atau 58\% dan berdasarkan lama beternak $88 \%$ rata-rata $>10$ tahun dan jumlah pakan $100 \%$ menggunakan limbah sisa pertanian.
\end{abstract}

Kata Kunci : Karakteristik Peternak, Sapi Bali 


\title{
EVALUATION OF FARMER CHARACTERISTICS ON BALI BEEF PRODUCTION IN BELU REGENCY, EAST NUSA TENGGARA
}

\begin{abstract}
The aims of this research was to study the influence of cattle society about the management of Balinese beef. This recearch was conducted in East Tasifeto and West Tasifeto of Belu Regency, East Nusa Tenggara in October - Desember 2018. The problem to know is how the characteristics of farmers to Bali beef production. The method used was an interview to 50 respondents of farmers. Purposive sampling techniques were used in this study and the variables observed include: education level, breeding age and long breeding of Balinese beef production. The experiment used descriptive statistics to analyze characteristics of the breeder. The result of this study is the characteristics of Balinese beef farmers in east Tasifeto and West Tasifeto subdistricts of Belu Regency based on the level of education most only protect primary school education as much as 27 people or $54 \%$, the average breeding age of 25-54 years or 58\% and based on the breeding age of $88 \%$ on average $>10$ years and the amount of feed $100 \%$ using waste waste agricultural waste.
\end{abstract}

Key words : Breeders caracteristics, Bali beef

\section{PENDAHULUAN}

Peranan sektor peternakan sebagai sumber pendapatan masyarakat berperan penting dalam meningkatkan kesejahteraan sosial bagi seluruh rakyat. Sektor peternakan juga mempunyai kontribusi yang besar bagi daerah, terutama dalam menumbuhkan peluang ekonomi masyarakat pedesaan (Salman dan Badr, 2011). Secara umum usaha peternakan di Kabupaten Belu masih dilakukan secara tradisional dan pemahaman masyarakat tentang penggunaan peralatan teknologi masih terbatas. Hal ini disebabkan oleh keterbatasan sumber modal dan tingkat pemahaman responden yang pada umumnya masih rendah, sehingga potensi yang ada belum dikelola secara baik dan efektif.

Sapi Bali adalah salah satu jenis ternak lokal yang dominan dibudidayakan oleh peternak di Kabupaten Belu. Hal tersebut 
dipengaruhi oleh beberapa keunggulan yang dimiliki oleh ternak sapi Bali, yakni: tingkat kapabiltas terhadap pakan berkualitas rendah sangat baik pada saat musim kemarau, memiliki kemampuan penyesuaian tinggi terhadap lingkungan dan mampu bertahan untuk tetap berproduksi baik di lahan kering (Baco, 2010). Selain itu, Sapi Bali mempunyai persentase karkas tinggi $(53,26 \%)$, tidak memiliki banyak lemak dan keempukan dagingnya tidak berbeda jauh dengan daging sapi impor (Murwanto, 2013). Di Kabupaten Belu Sapi Bali cukup memiliki peran dalam peningkatan kesejahteraan masyarakat sehingga dapat dijadikan sebagai komoditi unggulan yang perlu dikembangkan.

Ternak sapi Bali merupakan spesies unggulan di Kabupaten Belu, namun produktivitas ternak belum dikembangkan secara maksimal, hal ini diakibatkan oleh ketersediaan pakan yang dipengaruhi oleh musim, sehingga hijauan pakan akan melimpah pada saat musim hujan dan akan menurun pada saat musim kemarau (Bere, $d k k ., 2019$ ).

Sapi Bali memiliki keunggulan tersebut, namun perlu diadakan peningkatan terhadap produktivitasnya. Penurunan performans sapi Bali disebabkan oleh tidak adanya seleksi terhadap bibit yang unggul, sehingga terjadinya inbreeding (kawin sedarah) dan tidak dilakukan seleksi pejantan unggul yang digunakan sebagai pemacek sehingga terjadi perkawinan acak tanpa kontrol dalam kelompok (Baco, 2010). Ada beberapa faktor penentu tingkat produktivitas dan penampilan ternak yakni keturunan dan lingkungan (pakan, manajemen pemeliharaan, kesehatan, iklim dan sebagainya), akan tetapi faktorfaktor tersebut belum diperhatikan secara maksimal oleh peternak dalam pemeliharaan ternak sehingga mengakibatkan terjadinya penurunan terhadap populasi ternak. Oleh karena itu penelitian dilakukan untuk mengidentifikasi pengetahuan masyarakat peternak dalam memelihara Sapi Bali.

\section{METODE}

Penelitian ini telah dilakukan pada bulan Oktober - Desember 2018 di Kecamatan Tasifeto Timur dan Kecamatan Tasifeto Barat, Kabupaten Belu, Nusa Tenggara Timur. Populasi dalam penelitian ini meliputi semua peternak sapi potong yang berada di lokasi penelitian. Jumnlah sampel penelitian sebanyak 50 orang responden. Penelitian ini menggunakan metode purposive sampling dan menggunakan kusioner 
sebagai instrumen penelitian. Data yang digunakan dalam penelitian ini terdiri dari data primer dan data sekunder, meliputi: tingkat pendidikan, umur peternak, lama beternak dan jenis pakan yang diberikan kepada ternak. Penelitian ini menggunakan analisis statitistik deskriptif untuk mendeskripsikan karakteristik peternak. Jenis penelitian deskriptif kualitatif berupa wawancara, pengamatan secara menyeluruh maupun dengan kajian pustaka karakteristik peternak.

\section{HASIL DAN PEMBAHASAN}

\section{Hasil}

\section{Kondisi Geografis Kabupaten Belu}

Kabupaten Belu merupakan salah satu kabupaten di Propinsi Nusa Tenggara Timur yang berbatasan langsung dengan wilayah RDTL (Republik Demokrat Timor Leste) dengan luas wilayah 1.284,94 km2. Secara astronomis Kabupaten Belu terletak antara 1240-1260 Bujur Timur dan 90-100 Lintang Selatan. Berdasarkan letak geografisnya, Kabupaten Belu memiliki batas-batas: Utara-Selat Ombai. Selatan -Kabupaten Malaka. Timur-Negara Timor Leste. Barat-Kabupaten TTU (BPS Kab. Belu, 2017).

Kabupaten Belu dikenal dengan dua musim, sama halnya dengan Indonesia pada umumnya yaitu musim kemarau dan musim hujan. Secara umum, musim kemarau terjadi selama 7-8 bulan yakni dari bulan dari bulan April-November sedangkan musim hujan selama 3-4 bulan yakni dari bulan Desember-Maret (BPS Kab. Belu, 2018).

\section{Tingkat Pendidikan}

Menurut Baco (2011) menyatakan bahwa tingkat pendidikan akan berpengaruh terhadap kematangan diri seseorang dalam bersikap, pengambilan keputusan dan berperilaku. Tingkat pendidikan dapat diklasifikasikan menjadi lima bagian, yaitu: Tidak Sekolah, SR/SD, SLTP, SLTA dan Sarjana.

Hasil pengamatan menunjukkan rata-rata peternak yang tidak tamat SD sebanyak 6 orang atau $12 \%$ dari 50 orang responden, pendidikan SD sebanyak 27 orang atau $54 \%$ dari 50 orang responden, pendidikan SLTP sebanyak 9 orang atau $18 \%$ dari 50 responden, pendidikan SLTA sebanyak 8 orang atau $16 \%$ dari 50 orang responden. Hal ini menunjukkan bahwa peternak yang berpendidikan SR/SD sebanyak 27 orang dari 50 responden atau 54\%. Hal ini diduga bahwa umumnya 
responden lebih memilih jadi peternak dibanding mengayomi bangku pendidikan dengan alasan yang beragam sehingga peternak yang berada di Kabupaten Belu rata-rata hanya menyelesaikan pendidikan terakhir Sekolah Dasar (SD) atau sederajatnya atau bahkan tidak bersekolah. Menurut Warwick, $d k k$., (1995), pendidikan tidak sepenuhnya berpengaruh terhadap keberlangsungan usaha beternak, melainkan pengalaman beternak dan jumlah kepemilikanlah yang berpengaruh terhadap keberlangsungan usaha peternakan. Hasil penelitian ini berbeda dengan penelitian Makatita (2013) bahwa pendidikan merupakan salah satu faktor utama yang mendukung keberhasilan usaha beternak, dengan asumsi semakin tinggi tingkat pendidikan, semakin baik pengetahuannya untuk mengelola usaha. Tingkat pendidikan tersebut dapat dilihat pada Tabel 1.

Tabel 1. Tingkat pendidikan

\begin{tabular}{lcc}
\hline \multicolumn{1}{c}{ Tingkat Pendidikan } & Jumlah $($ orang) & Persentase(\%) \\
\hline Tidak Tamat SD & 6 & 12 \\
SD & 27 & 54 \\
SLTP & 9 & 18 \\
SLTA & 8 & 16 \\
Sarjana & 0 & 0 \\
& 50 & 100 \\
\hline
\end{tabular}

Keterangan: Data primer yang telah diolah (2018).

\section{Umur Peternak}

Umur merupakan faktor penting yang ikut mempengaruhi perilaku dan kinerja dalam suatu usaha yang dilakukan di mana tingkat intensifitas kerja akan meningkat apabila masih dalam kondisi sehat dan semakin menurun jika bertambahnya umur seseorang. Pengelompokkan umur terdiri atas 3 (tiga) kelompok besar yaitu: usia tidak produktif antara $<24$ tahun, usia produktif 25-54 tahun, usia tidak produktif $>56$ tahun.

Menurut Ahmadi, dkk (2017) menyatakan bahwa umur merupakan suatu tingkat kedewasaan seseorang dalam pengambilan suatu keputusan, dan berpengaruh juga terhadap pengalaman yang dimiliki, semakin bertambah umur seseorang maka pengalaman yang dimiliki semakin tinggi begitu juga sebaliknya, akan semakin sedikit pengalaman yang dimiliki jika umur seseorang dikatakan relatif lebih muda. Data karakteristik peternak terdapat pada Tabel 2. 
Tabel 2. Umur peternak

\begin{tabular}{lrc}
\hline Jenis Umur (Tahun) & Jumlah (orang) & Persentase(\%) \\
\hline$<24$ & 0 & 0 \\
$25-54$ & 29 & 58 \\
$55-80$ & 21 & 42 \\
Total & 50 & 100 \\
\hline
\end{tabular}

Keterangan: Data primer yang telah diolah (2018)

\section{Lama Beternak}

Pengalaman usaha yang telah terpatri dalam diri seseorang akan turut mempengaruhi sikap dan perilakunya dalam bertindak. Oleh karena itu perlu dideskripsikan karakteristik peternak sesuai pengalaman beternak. Klasifikasi karakteristik peternak berdasarkan lama beternak dapat dilihat pada Tabel 3.

Tabel 3. Pengalaman beternak

\begin{tabular}{lll}
\hline Pengalaman Beternak & Jumlah (orang) & Persentase(\%) \\
\hline $1-5$ tahun & 0 & 0 \\
6-10 tahun & 6 & 12 \\
$>10$ tahun & 44 & 88 \\
Total & 50 & 100 \\
\hline
\end{tabular}

Keterangan: Data primer yang telah diolah (2018)

\section{Pakan Yang Digunakan \\ Produksi Hijauan}

Komposisi padang penggembalaan di kecamatan Tasifeto Timur dan Tasifeto Barat banyak di dominasi rumput alang-alang dan sulit ditemukan leguminosa. Hal ini dipengaruhi oleh musim yang telah memasuki musim kemarau pada saat penelitian berlangsung sehingga hanya jenis rumput yang mampu bertahan pada iklim panas dan ketersediaan jenis hijauan relatif sama.

Menurut Rauf, $d k k$ (2015) mengatakan bahwa musim hujan sangat berpengaruh terhadap kualitas dan kuantitas produksi rumput. Dari segi kualitas pada musim kemarau mengakibatkan adanya perubahan nilai gizi rumput karena berasal dari unsur hara dalam tanah. penurunan kadar air tanah pada musim kemarau, mengakibatkan kandungan unsur hara kurang diabsorbsi rumput untuk pembentukan 
zat gizi, maka beberapa kandungan zat gizi akan menurun, salah satunya adalah kandungan protein kasar. Selain itu radiasi sinar matahari yang lebih besar pada musim kemarau mengakibatkan peningkatan pembentukan serat kasar. Kuantitas rumput pun menurun karena rendahnya kadar air dalam tanah, maka akan terjadi penghambatan terhadap pertumbuhan rumput (Dimas, $d k k ., 2013$ ).

Untuk mengetahui jawaban responden peternak sapi Bali di Kecamatan Tasifeto Timur, tentang pemberian pakan pada ternaknya dapat dilihat pada Tabel 4.

Tabel 4. Jenis pakan yang diberikan pada ternak.

\begin{tabular}{lll}
\hline Jenis Pakan & Ya $(\%)$ & Tidak $(\%)$ \\
\hline Jerami Padi & 100 & 0 \\
Jerami Kacang-Kacangan & 100 & 0 \\
Batang Pisang & 54 & 46 \\
Jerami Fermentasi & 38 & 62 \\
\hline
\end{tabular}

Keterangan: Data primer yang telah dolah (2018)

\section{Pembahasan}

\section{Karakterisitik Peternak di Kabupaten Belu.}

\section{Tingkat pendidikan}

Hasil pengamatan menunjukkan bahwa jika dikonversi pada tingkat pendidikannya, membuktikan bahwa sebagian peternak hanya menyelesaikan pendidikan Sekolah Dasar. Secara keseluruhan dapat dikatakan bahwa pendidikan peternak belum cukup baik dan hal ini sangat mempengaruhi dalam usaha mereka dalam mengakses informasi dan inovasi terkait dengan usaha beternak sapi Bali yang mereka lakukan.

Murwanto (2008) mengatakan salah satu indikator untuk mengetahui kualitas masyarakat dan merupakan peubah kunci dalam pengembangan sumberdaya manusia adalah tingkat pendidikan.

\section{Umur}

Hasil penelitian (Tabel 2) menunjukkan bahwa umumnya peternak di Kabupaten Belu masih berada di usia yang produktif, yaitu sebanyak 29 orang atau $58 \%$. Sementara usia manula sebanyak 21 orang atau $42 \%$. Hal ini bahwa peternak di Kabupaten Belu memiliki semangat yang tinggi untuk melakukan usaha beternak. Menurut Murwanto, (2008) mengemukakan bahwa peternak yang berumur produktif 
memiliki pemikiran yang dinamis dan bentuk fisik yang baik dan sehat dalam mengelola usahanya. Selain itu menurut Chamdi (2003) bahwa semakin muda usia seseorang (20-45 tahun) maka rasa ingin tahu terhadap sesuatu dan kemampuan untuk mengadopsi teknologi semakin tinggi.

Suwanda (2018) mengemukakan bahwa peternak yang sudah berusia lanjut sangat terpaku terhadap tradisi dan sulit untuk diberikan pengertian-pengertian yang dapat mengubah pola berpikir dan cara pandang dalam upaya peningkatan terhadap kemajuan dalam usahnya.

Partisipasi kerja seseorang dalam keberlangsungan hidupnya juga dipengaruhi oleh faktor umur (Fauziyah, $d k k$., 2015). Semakin bertambah usia seseorang semakin bertambah partisipasinya, namun akan menurun pada usia tertentu ketika kekuatan fisik mulai menurun. Faktor usia akan sangat berpengaruh pada pekerjaan yang sangat mengandalkan kekuatan fisik. Usia sangat mempengaruhi produktivitas kerja karena lebih dominan mengandalkan kekuatan fisik (Ahmadi, $d k k .$, 2017)

\section{Lama Beternak}

Hasil penelitian (Tabel 3) menunjukkan bahwa dari jawaban kuisioner responden dapat dilihat karakteristik peternak beradasarkan pengalaman beternak bahwa rata - rata sudah melakukan pemeliharaan ternak lebih dari 5 tahun, yaitu antara 6 - 10 tahun sebanyak 6 orang atau $12 \%$, pengalaman beternak $>10$ tahun sebanyak 44 orang atau $88 \%$. Hasil penelitian ini menunjukkan bahwa faktor yang sangat menentukan keberhasilan suatu usaha peternakan adalah pengalaman beternak, dengan pengalamannya maka peternak mempunyai pedoman yang sangat baik untuk melakukan usahanya. Selain itu umur dan pengalaman beternak berpengaruh terhadap kemampuan peternak untuk melakukan suatu usaha peternakan dan akan sangat berhati-hati sebelum mengambil keputusan dan bertindak dengan belajar dari pengalaman-pengalaman yang sebelumnya. Hal ini sebanding dengan pendapat Idris, $d k k$., (2009) bahwa pengalaman beternak berkorelasi nyata dengan skala usaha ternak dan juga minat dipengaruhi oleh pengalaman beternak karena pengalaman beternak yang semakin lama maka semakin tinggi minat untuk mengembangkannya. 


\section{Jenis Pakan yang digunakan \\ Produksi Hijauan}

Berdasarkan Tabel 4 dapat dikatakan bahwa hampir semua responden menggunakan limbah sisa pertanian, jerami kacangkacangan dan batang pisang.. Hal ini dikarenakan semua pakan tersebut banyak tersedia di seluruh kecamatan Tasifeto Timur yang mayoritas penduduknya berprofesi sebagai petani. Jenis-jenis pakan tersebut merupakan pakan utama ternak sapi Bali yang ada di kecamatan Tasifeto Timur pada saat musim kemarau. Sedangkan jenis pakan fermentasi buatan sendiri yang diberikan pada ternak hanya $38 \%$ dari total jumlah responden. Hal ini dikarenakan dalam proses pembuatan pakan fermentasi membutuhkan waktu dan tenaga, sedangkan responden memiliki pekerjaan lain, yakni petani dan pedagang.

\section{SIMPULAN}

Berdasarkan hasil peneltian dapat disimpulkan bahwa:

1. Tingkat pendidikan peternak yang ada di Kecamatan Tasifeto Timur dan Tasifeto Barat sebagian besar hanya mengayomi tingkat pendidikan Sekolah Dasar sebanyak 27 orang atau 54\% dari 50 responden peternak

2. Umur peternak, sebagian besar peternak berumur $25-54$ tahun atau $58 \%$ dari 50 responden peternak

3. Pengalaman lama beternak sebanyak $88 \%$ rata-rata $>10$ tahun.

4. Pakan yang digunakan oleh responden $100 \%$ menggunakan limbah pertanian (jerami padi dan jerami kacang-kacangan).

\section{UACAPAN TERIMA KASIH}

Saya mengucapkan limpah terima kasih kepada semua pihak yang telah mendukung dan terlibat dalam penelitian ini.

\section{DAFTAR PUSTAKA}

Ahmadi Y. N., Solikin N., dan Andaruisworo S. (2017). Characteristics of beef cattle farmers in the district of kediri district badas. Jurnal Universitas Nusantara PGRI Kediri. 
Baco S. (2010). Performances of bali cattle

Baco S. (2011). Konservasi sapi Bali sebagai plasma nutfah ternak Indonesia. Buletin peternakan. volume 40. hal: 12-21

Badan Pusat Statistik. (2018). Belu dalam angka.

Badan Pusat Statistik. (2017). Belu dalam angka.

Bere, E. K., Woro Busono dan Sri W. (2019). Production performances of bali cattle reared at different altitudes in Belu District, East Nusa Tenggara, Indonesia. International Research Journal of Advanced engineering and Science. Vol 4. Pp: 88-90.

Chamdi A. N. (2003). Kajian profil sosial ekonomi usaha kambing di kecamatan kradenan kabupaten Grobongan. Seminar nasional teknologi peternakan dan veteriner: Bogor.

Dinas Peternakan Kabupaten Belu. (2017). Populasi sapi bali di kabupaten Belu.

Fauziyah D., Nurmalina R., dan Burhanuddin. (2015). Pengaruh karakteristik peternak melalui kompetensi peternak terhadap kinerja usaha ternak sapi potong di Kabupaten Bandung. Jurnal Agribisnis Indonesia. 3 (2). Halaman 83-96.

Idris N., Alfiani H. dan Fatati. (2009). Minat peternak untuk mengembangkan ternak sapi di kawasan perkebunan sawit. Program Studi Ekonomi Peternakan. Universitas Jambi. Jurnal Penelitian Universitas Jambi Seri Humaniora. 11(2). ISSN 0852-8349.

Makatita J. (2013). Hubungan antara karakteristik peternak dengan skala usaha pada usaha peternakan kambing di kecamatan Leihitu, kabupaten Maluku Tengah. Agrinimal, 3(2) pp:78-83. 
Mirah E Riko, E. K. M. Endoh, J. Pandey dan A. H. S Salendu. (2015). Potensi pengembangan ternak sapi pada usaha tani di kecamatan Tarean. Jurnal Zootek. 35 (1) pp : 46-54. ISSN 0852-2526

Murwanto A. G. (2008). Karakteristik peternak dan tingkat masukan teknologi peternakan sapi bali di lembah prafi kabupaten Manokwari. Jurnal Ilmu Peternakan. 3 (1) pp: 8-15.

Rauf, A., Priyanto, R., dan Panca, D.M.H.K.S. (2015). Produktivitas sapi bali pada padang penggembalaan di kabupaten bombana. Jurnal Ilmu Peternakan dan Teknologi Hasil Peternakan. 3 (2) pp: 100-105.

Salman D.M., Badr K. (2011). Linking entrepreneurship and total factor produktivity what are the economic setting required. Seminar internasional politics and economic development 20-22 Maret 2011. Turki: Ekonomic Research Forum.

Sudjana. (2001). Metode dan teknik pembelajaran partisipatif. Bandung : Falah Production.

Sugiyono. (2012). Metode Penelitian Pendidikan Pendekatan Kuantitatif, Kualitatif dan $R \& " D$. Bandung : Alfabeta. 
Suwanda, Y. (2018). Analisis karakteristik dan pendapatan usaha ternak sapi potong di kecamatan Sitiung kabupaten Dhamasraya. Diploma Thesis. e-Skripsi Universitas Andalas.

Warwick, E. J. J. M. Astuti and Harjosubroto W. (1995). Pemuliaan Ternak. Cetakan Kelima. Universitas Gajah Mada,. Press. Yogyakarta.

Zurahmah N. (2011). Penduga bobot badan calon pejantan sapi bali menggunakan dimensi ukuran tunuh. Bulletin Peternakan 35 (3) pp:160-164 